\title{
Terrorism as the Quest for Justice in Contemporary Nigeria
}

\author{
Peter Akpo Adams \\ https://dx.doi.org/10.4314/ujah.v22i2.4
}

\begin{abstract}
In Nigeria today, the activities of terrorists are no longer new. This is what has characterized the Nigerian state. This hydra-headed monster with its attendant heinous crimes against humanity is the main focus of this paper. In this paper, the problem of terrorism has been discussed from a two dimensional continuum - of terrorist acts as the quest for justice in contemporary Nigeria, and on the other hand, the paper examines the phenomenon as an unjust, inhuman and wicked means implored by the jihadi movement to cause fear among Nigerians. The paper made use of content analysis for its research methodology. The paper leaned on the rational choice theory and the psychological approach. The paper concluded by maintaining the view that no matter the level of provocation or injustice in the social system, terrorist acts remain unfair and inhuman. The actions of terrorists therefore, can never be justified by any measure, human or otherwise.
\end{abstract}

\section{Introduction}

Acts of terror have grown exponentially in Nigeria. Since July 2009 when an attack was launched by Boko Haram on a police station in Bauchi State, there has never been peace within the Nigerian clime. One act of terrorism after the other is recorded almost daily in Nigeria, especially within the northeast of the country. Could these acts of terrorism be a quest for justice in contemporary Nigeria? The perpetrators of this heinous crime against humanity - the Boko Haram insurgents and its splinter groups such as the Islamic State 
of West African Province (ISWAP), killer herdsmen and kidnappers are bent on overthrowing the country and turning Nigeria into an Islamic state.

It is also germane to note that not too long ago, Nigeria had had to struggle with oil militants in the southern part of the country, particularly in the oil rich Niger Delta of the so-called South-South. However, the spike in cattle militancy in the northern part of the Nigerian State, is more devastating and destructive because of its collateral demand on the economy of northern of Nigeria. Little wonder, scholars such as Imhonopi and Urim (2016) and Ojewale (2021) concluded that it is terrorism that has led to poor economic development in northern Nigeria. Ojewale in particular, opines that there exists, a link between terrorism and economic backwardness in northern Nigeria.

This paper discusses the issues of terrorism from a twodimensional continuum of terrorist acts as the quest for justice in contemporary Nigeria, and on the other side of the continuum, it sees the phenomenon as an unjust means imported by the Jihadi movement for whatever reason that they are terrorizing the Nigerian citizenry. This paper also seeks to maintain the view that any act of terrorism cannot be seen as a quest for justice, no matter what may be the casual factors of terrorism or the motive behind every act of terrorism. The main aim of this paper is to show that no matter the level of injustice in the land, caused either by individuals or systemic failures of the Nigerian state, the resolve to use terror or any form of violence is not the best approach of resolving any grievances. This paper adopts the rational choice theory and the psychological approach for its theoretical framework and made use of content analysis of secondary data. 


\section{Conceptual Clarification}

There is difficulty in arriving at any consensual definition of such a complex phenomenon as terrorism. There are as many definitions of the concept as there are different definers. The reason for this lack of unanimity is basically because the term terrorism is often explained as a concept that is pejorative in nature. On the other hand, it could also be that the term is often interpreted and used in an emotions-charged atmosphere. These emotions could emanate from a pre-conceived sense of death, brutality or violence and war as the case may be. In the same line of thought, justice is variously interpreted from different cultural backgrounds. For instance, the Islamic jihadists see their acts of terrorism as being a just war to get rid of infidels. The various definitions of terrorism and justice notwithstanding, the following definitions shall suffice. Defining terrorism, Endner and Sandler (2002) write:

Terrorism is the premeditated use of threat of use of violence by sub-national groups to obtain a political, religious or ideological objective through frightening of a huge audience, usually not directly involved with policy making that the terrorists seek to influence. $(145-146)$.

Rugby (2002) citing the United State Department of State sees terrorism as "politically motivated violence perpetrated against noncombatant targets by subnational groups or clandestine agents, usually intended to influence an Audience" (p.10). According to Chomsky (2001) "terrorism is the use of forceful means to achieve political, religious, or other aims" (p. 19). Tilly (2004) sees terrorism as an "asymmetrical deployment of threats and violence against enemies..." (p. 5). To Stern (1999), terrorism is "an act or threat of violence against non-combatants, with the objective of frightening or otherwise changing an audience or 
audiences" (p.30). Chalk (1999) also defines terrorism as "the systematic use of violence that is employed by sub-state actors as means of achieving specific political objectives, these goals differing according to the group concerned" (p. 151). To Lizardo (2008) "terrorism may be part of the cycles and trends of interest in the world system, responding to the same broad families of global dynamics as other forms of system-level conflict" (p. 91).

On the other hand, justice is also variously defined by different scholars. To Rawls (1971) justice simply means fairness. According to Ferguson (1984) the concept justice stands for: "(1) the quality of being just, fair or impartial; even handedness. (2) Adherence to truth or facts, validity, correctness. (3) The rendering of what is due or merited, also that which is done or merited. (4) Conformity to right principles, honesty, integrity (5) a judge" (p. 392). The Webster's Integrated Dictionary and Thesaurus (2006) defines justice as "amends, appositeness, appropriateness, compensation, correction, dharma, equitableness" (p. 509). The Webster's Universal Dictionary and Thesaurus (2008) defines justice as "justness; fairness; the use of authority to maintain what is just; the administration of law; a judge" (p. 271).

Citing Thomas Aquinas, Nzomiwu (2012) avers that justice is "a habit whereby man renders to another his due by constant and perpetual will" (p. 31). From the few definitions of justice given above, it is the obvious that the term justice has various interpretations and applications. Each scholar's definition seems to be influenced by his/her background or socio-cultural milieu. The various definitions given above, do not by any means, fit the concept as perceived and understood by Islamist Jihadists in 
northern Nigeria. Their perception of the concept is therefore, immoderate, deficient, irrational, unfounded and ill-conceived.

\section{Theoretical framework}

In order to establish academic relevance and to also add impetus to this paper, there is need for the paper to lean on a theory. The two theories used herein are the rational choice theory and the psychological approach. It must also be added herein that there are a million and one literature on the subject of terrorism, history of terrorism and rule of terror, but literature in the area of theoretical perspectives have not been adequately developed to their fullest extent. This is partly due to the hydra-headed nature of the concept of terrorism.

Rational choice theory, according to Crossman (2017), was pioneered by the sociologist George Homas. In 1961, Homas laid the basic framework for exchange theory. This exchange theory, he later grounded in the assumption gotten from behavioural psychology. After Homas had this foundation, it became obvious that rational choice theory has to do with economic principles. This is because economics plays a role in human behaviour, especially when it comes to calculating the costs and benefits of one's action. This, therefore, means that people are motivated by money and the possibility of making gain, calculating also the cost. This manner of thinking is a kind of rationalizing between two options. Between the 1960s and 1970s, theorists like Blau, Coleman and Cook took interest in the rational choice theory and helped to develop, according to Crossman (2017) a more formal model of rational choice theory. Since then, it has come to be applied by various scholars in diverse fields of endeavours. Crossman writes: "Over the years, rational choice theorists have 
become increasingly mathematical. Even Marxists have come to see rational choice theory as the basis of a Marxist theory of class and exploitation" (p. 1). Could the above assertion justify terrorists act in Northern Nigeria, giving that some of them feel exploited and improverished by the elite of society? If this is so, then it is a false and faulty perception of their struggle.

Moss (2016) also lends his voice in support of the wide applicability of the rational choice theory. He opines: "The rational choice theory of terrorism assumes that terrorist acts usually emanate from rational, calculated, conscious decision. These decisions represent an optimal strategy to fulfil the sociopolitical goals of these perpetrators" (p. 1). Other scholars that argue in support of this assertion are Crenshaw (1992), Wilson (2000) and Victoroff (2005). It must also be noted here that the rational choice theory share basic principles with the game theory. This is so because the game theory also makes use of situations where people either gain or loss at the expense of others. This is what is called zero-sum game. Thus, there is clear evidence that shows that some of the actions of terrorists appear to be intentional, purposeful and directed to maximize their said goals or targets. On the contrary, there are also sufficient evidence to show that terrorist behaviour could be as a result of insanity and complex childhood issues as a result of poor parental upbringing. Spiering (2015) and the SBM intelligence (2021) report that most atrocities committed by terrorist, showcase them as abnormal individuals.

The psychological approach on the other, has to do with literature that produce profiles of terrorists with specific attention given to why terrorists embark on such acts, who are they, and what are their common features if need be. Ozdamar (2008) maintains 
the view that there are two approaches within the psychological explanation that dominate literature in this area. The first approach are those psychologists who hold the opinion that terrorists are psychopaths and therefore, people who commit such crimes are abnormal or mentally deranged. This view is however, heavily criticized for several reasons. One of such criticisms comes from Ozdamar (2008). He writes: "However, such an approach is reductionist and far from being able to explain different dynamics of such a complex phenomenon. This approach excludes the political, ideological, economic and sociological factors that lead people to become terrorists" (p. 98).

The major criticism of this first approach however, stems from lack of $100 \%$ scientific evidence. This poor scientific evidence is what made Borum (2004) to assert that "psychology, as a discipline, has a long history of (perhaps even a bias toward) looking first to explain deviant behaviours as a function of psychopathology (that is, mental disease, disorder, or dysfunction) or maladjusted personality syndromes" (p. 30). However, researches such as those of McCauley (2002) and Sageman (2004) point to the fact that there is fairly any consistency in finding serious psychopathological issues among terrorists. Other literatures in this line of thought are those of Corado (1981), Friedland (1992), Silke (1998) and Ruby (2004). All these studies above show that there is no 'compelling evidence' that terrorists are mentally deranged persons. There may be some slight variations in some cases.

On the other hand, the second approach views terrorists as fanatics who are rational, calculated and logical individuals, whose rewards according to Ozdamar (2008) "....are ideological and political, rather than financial" (p. 98). He further states: "This 
approach characterizes terrorists as well-educated and sophisticated people who are capable of using advanced rhetoric and political analysis" (p. 98). What this means is that terrorists could possess a mindset that views the world from a particular perspective that could result in any violent act. In view of these prevailing arguments, it ought to be noted that in which ever cases, there is no one word in any terrorist's act. Whether terrorist actions are motivated by ideological, political and religious views, or are influenced by any form of mental disorder or 'maladjusted personality syndrome' as posited by Borum (2004), terrorism is a condemnable act on all fronts.

\section{Terrorism: Causal factors and experiences of the Nigerian State}

The causes of Boko Haram terrorism in Nigeria are myriad, hence there are no unanimously agreed upon causes. Each scholar views the causes from his or her standpoint. However, among the very many causes, Obiefuna and Aadms (2017) list the following to be major causes: Poverty, the almajiri factor, corruption on the part of the government, teeming population of unemployed youths, high rate of illiteracy, culture of violence and youth anger over unfulfilled government programmes and projects. There is also the root of the Maitatsine upring, up to the 2009 when the Islamic jihadi sect had confrontation with the Nigerian security operatives. Mention must also be made of the fundamentalist ideology among some fanatical Muslims among others. In fact, Adams (2017) maintains that there is a nexus between religious fundamentalism and global terrorisms. He explain further on this connectivity when he avers thus: 
The Osama Bin Laden's terrorist attack of the World Trade Centre and the Pentagon, all in the United States of America in September 11, 2011, showed beyond doubt that religious beliefs and/or institutionalized religious have not died in the face of modernism. (17).

It is beyond the scope of this paper to expatiate further on each of those factors mentioned above. On the other side of the continuum, are the various effects of terrorism on the Nigerian state. Studies such as those of Ekanola (2006), Campbell (2012), Erne and Ibletan (2012), Afeno (2012), Adenrele (2012), and Ome, and Casmir (2015) have all shown that the presence of Boko Hararn terrorism has threatened the unity, peace, progress and security of this country. In addition to the above effects, Onuoha (2012), Adele (2013) and Buba (2015) agree that the economy of Nigeria has been affected as a result of the activities of Boko Haram terrorists. Throwing more lights on these effects Obiefuna and Adams (2021) observe that acts of terrorism in Nigeria, especially in north east Nigeria have left many people, especially females homeless and displaced. They write that "these circumstances affect female IDPs who are the worst hit, especially lactating mothers who keep moving from one makeshift settlement to another in order to make ends meet" (p.3). In addition, Adams (2019) declares that religious violence led to "displacement and loss of identity (p.95).

To Barna (2014) and Gardner (2014), terrorists' activities, especially in the northeast of the country, have caused many people to be displaced, resulted in so many people's death and several untold hardship on the victims of the communities they have raided. It is estimated that between July 2009 and July 2014, over 13,000 people have lost their lives to the activities of the Boko Haram 
terrorists. It is even said that this figure is a conservative estimate as there can never be an accurate estimate of the death toll. As a result of this death toll, there has been forced migration from the northeastern region of the country. It is therefore, as a result of this that Rogers (2012) reports that the U.S government has asked its citizens to leave the 'war' zone of the northeast of Nigeria. Apart from the above listed challenges, Adams (2017) further states that religious terrorism in northern Nigeria has led to the violation of fundamental human rights of citizens especially those in Kaduna state. He posits thus: The direct consequences of the above causes of violence in southern Kaduna are the obvious depersonalization denial, and abuse of the fundamental human rights of Christian indigenes in the aforementioned zone" (p.28).

\section{Terrorist acts: The quest for justice in contemporary Nigeria}

Having examined the two theories discussed above and whereas it has been established that there is no $100 \%$ scientific evidence that terrorists are psychopaths, there is need to examine herein, the quest by terrorist to bring justice in contemporary Nigeria. The question now is, what type of terrorism could bring about the quest for justice in any society? Looking at the various characterizations of terrorism, one would say that the Boko Haram terror group could be classified as repressive terrorism since it targets the government, the educational system, groups/organizations, individuals or forms of behaviours which they see as polluting the Islamic religious tradition. This, they (Boko Haram terrorists) do consciously, hence the rationale for using the rational choice theory in this paper. In fact, to support the above view, Buba (2015) and Spiering (2015) maintain that terrorists do all these using religion as a backdrop. 
It is also on this note that one may not doubt the attack launched by the Boko Hararn members on ,Girls Secondary School, Chibok and several other similar attacks and kidnappings, since the terrorists feel and do believe strongly that a girl of nine years is of marriageable age. The philosophy behind the attacks is that the girls were not supposed to be in schools but in their husbands' houses. This is backed by the philosophy behind the formation and of course the name - Boko Haram which means Western education is forbidden. According to Victoroff (2005) most Islamic fundamentalists hold the view that a girl is not supposed to see her menstrual circle twice in her father's house. With this fundamentalist doctrinal teachings and backgrounds, the terrorists justify their acts as being a just course and of course approved by God, who according to these fanatics, does not only supports it, but demands of it. So, they are fighting injustice in the system.

This, of course justifies the three attributes of terrorism as advanced by Hoffman (1997). According to Hoffman, these traits are: (a) the perpetrators must use religious scriptures to justify or explain their violent acts or to gain recruits, (b) clerical figures must be involved in leadership roles, (c) perpetrators use apocalyptic images of destruction to justify the acts. All these three traits fits, perfectly, the Nigerian terror groups- Boko Haram, and killer herdsmen. All the three characteristics as advanced by Hoffman have been exhibited at one level or instance of their atrocities within the Nigerian clime.

Now to the crux of the matter, one of the strongest point and most frequently cited argument in defence of terrorism is the struggle against aggression. Fotion, Kashnikov and Lekea (2007) cite a good number of instances. They write: "The Palestinians use 
this argument against the Israeli invaders... Hezbollah, in it 'Programme' also sees itself as a fighter against aggression..., Osama Bin Laden also sees himself and those, who fight with him as opposing aggression" (pp. 120-121). They further add that "a variant of this argument focuses on liberation" (p. 121). They also cite other examples to include the Palestinians, the Provisional Republican Army among a host of others. Here in Nigeria, the above arguments also hold sway as the Boko Haram members, Islamic State of West African Province (ISWAP) fighters, armed bandits and killers herdsmen are often quoted to have said that, their confrontation with the Nigerian security forces remains an act of aggression against them. They believed that their reprisal attacks and other atrocities are justified because they were aggressively dealt with by the Nigerian police. Considering the second variant argument which focuses on liberation, they (terrorists) also believe that by their jihadi actions, they seek to liberate their people, especially those in the northeast of the country from the shackels of western education and civilization which they see as evil. All these they do, because that they are fighting a just cause - Jus $a d$ bellum.

Another principle that needs to be given attention is the Jus ad bellum (other principles). Fotion, Kashnikov and Lekea (2007) further write that terrorist use this argument to show that their intentions are pure and are right, and hence, in accord with just cause. They perceive the enemies' intentions as impure and therefore wrong. Writing further, the trio notes: "One Jus ad bellum principle that tends to get more attention is last resort. Many terrorists tend to claim that other means before violence have been tried" (p. 125). These other means could be negotiations. In the case 
of Nigeria however, there has never been any form of negotiation. In fact, the jihadi sect has consistently refused to come to the negotiation table. So, this second argument does not hold any weight. It may have happened elsewhere, but not in Nigeria, where the terrorists have forcefully seized communities and declared them Boko Haram communities.

Another strong argument in this just war theory is the in bello arguments. Fotion, Kashnikov and Lekea (2007) assert: "Terrorists have a slew of arguments to justify their terrorism. One of these is the revenge argument that can be expressed as 'Do unto others because they do it unto you and as they do unto you'" (p. 128). The most nearest instance locally, that is, here in Nigeria, is Boko Haram's claim that they strike because their sect members and leaders were seized and put behind bars without due process. The imprisonment and detention of their leaders and sect members in Bauchi State and that of the Shiite leader by the Federal Government of Nigeria are case in focus. They therefore, claim that every atrocity committed is a kind of revenge mission. The mere fact that they claim these actions is a further proof that they are not psychopaths and that these decisions are purposefully taken, hence, the justification for using the rational choice theory herein. This view is also maintained by Moss (2016).

\section{De-emphasizing terrorist acts and the arguments against terrorism}

Terrorist acts have been perceived by many as acts of injustice because there are other options to sue for peace. For instance, the use of negotiation instead of using violence. This criticism is apt because violence is inhuman and as Ogundiya and Amzat (2008) would say, "is also devastating and therefore should be controlled" 
(p. 185). No matter how strong the argument for terrorism could be, it can never be superior to that against terrorism. Take for instance, the irrational and deliberate invasion of Chibok and the subsequent carting away of over 264 innocent school girls in April 2014 and other subsequent adoptions. What is the moral justification for such terrorist atrocities? What have the school girls done to warrant such heinous treatment? They are neither at the hem of affairs of the Nigerian state nor are they policy makers, who make decisions that are unislamic. This action of the Islamic jihadi sects is an evidence that terrorists lack patience and normally do not want to explore options like peaceful negotiation.

Another criticism, seen as an injustice is the use of what Fotion, Kashnikov and Lekea (2007) called "terrorist rhetorics" (p. 139). What that means is that terrorists usually exaggerate, distort and deceive people by claiming to be fighting a just cause. Another case in point is the video that went viral on May $5^{\text {th }} 2014$, in which Abubakar Shekau, the acclaimed leader of the Boko Haram terror group claimed sole responsibility for the abduction of the Chibok girls. He also said how this act is justified and in fact demanded by God and that slavery is permitted in Islam and that he would sale them for they were supposed to be in their husband houses and not schools, since western education is a sin. However, to show how unjustified and unislamic this act was, several Islamic religious leaders, the world over condemned the incident. This shows that even the just cause principle does not apply in all cases and is not justified in all circumstances, place and time. The idea of discrimination is another criticism levelled against terrorists' acts. Fotion, Kashnikov and Lekea (2007) aver that in spite, of severe 
criticisms against terrorists, they are still adamant for the following reasons:

(1) They take advantage on the immoral behaviour of their enemies;

(2) They attack the 'innocent' in self-defence in situation where they cannot act otherwise (the necessity argument); and

(3) They insist that so-called 'innocent' are not really innocent (argument from collective responsibility). (142-143).

The above arguments notwithstanding, there is no moral justification for terrorists to embark on violent acts. Besides, in several cases, it is not the supposed enemies to terrorists that strike first, but rather, they (terrorists) strike first. So, the issue of revenge does not also apply in all case, circumstances and space. Given, for example, the Nigerian terror group, which is driven by a jihadi agenda to Islamize Nigeria, where lies the principle of revenge, since it is an established fact that the terrorists have nursed these ideas, planted them, they have germinated, sprouted, grown and are yielding fruits? This is how the Maitatsine started and it eventually gave birth to Boko Haram with the jihadi agenda that has been the driving force, propelling all their atrocities.

Again, the principle of the innocent has been elaborately discussed above. Now the idea of collective responsibility. This idea also holds no water because when terrorists claim that a particular regime or administration "commit" any form of aggression against them (for example, the American-Iraqi war, where Iraqi people were killed) and therefore any one from that region, state or country is a target does not apply also in all cases, 
circumstance and time. These and several other criticisms are clear evidence that acts of terrorism can never be justified.

\section{Conclusion}

Terrorism has become ubiquitous, albeit its presence in Nigeria is relatively recent and new. This hydra-headed phenomenon has become a reality that stare every Nigerian in the face. The citizens are not certain if the proactive measures taken by the Nigerian state and its allied forces are yielding any positive result. The heinous atrocities committed by the terrorists have created an awareness and consciousness in Nigerians that far surpasses that of the years of its early beginning. Nowhere in the world is any act of terrorism justified. In this paper, it is argued that any act of terrorism is an injustice. The paper however, balanced the view on terrorism by examining acts, principles and doctrines supporting or justifying terrorist acts, but also advances reasons why their activities are seen as unjust, both locally and globally. Instances were drawn from the global arena, both efforts were also made to situate these instances within the Nigerian context. The paper concludes by maintaining the view that terrorism in whichever form is unjust and therefore, should be controlled and de-emphasized.

Peter A. Adams is of the of Department Of Religious And Cultural Studies, Faculty Of Arts, University Of Calabar Calabar adams.akpo@unical.edu.ng; akpopeter26@gmail.com; adamspeter82@yahoo.com 


\section{References}

Adams, P. A. (2017). Has religion become an epiphenomenon? Facts from Boko Haram insurgency in North Eastern Nigeria. Conference Proceedings- University of Nigerian, Nsukka, 14-23.

Adams, P. A. (2017). Violation of fundamental human rights: The experience of Christians in Southern Kaduna State Nigeria. Conference Proceedings- University of Nigerian, Nsukka. 24-37.

Adams, P. A. (2019). Religious violence and migration crises in North east Nigeria. Journal of African Studies and Sustainable Development, 2, 6, 90-102.

Adele, B.J. (2013). The Boko Haram crisis and Nigeria's external relations. British Journal of Arts and Social Sciences, 11, 11, 126-139.

Adenrele, A.R. (2012). Boko Haram insurgency in Nigeria as a symptom of poverty and political alienation. Journal of Humanities and Social Science (JHSS), 3, 5, 21-26.

Afeno, O.S. (2012). The Boko Haram uprising and insecurity in Nigeria: Intelligence failure or bad government? Conflict Trends, 1, 35-41.

Barna, J. (2014). Insecurity in context: The rise of Boko Haram in Nigeria. The policy department DG Expo. Online @ http://www.europarl.europa.eu/ReRData/etudes/note/join/ 
2014/53693/EXPQ-AFET-NTf2014)536393.EN.pdf. Accessed 5th October, 2014.

Borum, R. (2004). Psychology of terrorism. Tampa: University of South Florida Press.

Buba, LA. (2015). Terrorism and rape in Nigeria: A cry for justice. Arabian Journal of Business and Management Review (OMAN Chapter) 4, 11, 1-12, Online @ http://www.arabianibmr.com/pk/OM-vol-4-ll.pdf. Accessed October, 2017.

Campbell, J. \& Harwood, A. (2012). Boko Haram and Nigeria's pervasive violence. Council on foreign relations. Online @ http: / / www. cfr.org / nigeria/ boko-haramnigerias-pervasive-violence/p29706. Accessed $5^{\text {th }}$ October, 2013.

Chalk, P. (1999). The evolving dynamics of terrorism in the 1990s. Australian Journal of International Affairs. 53, 151-167.

Chomsky, N. (2001). 9-77. New York: Seven Stories.

Corrado, R. (1981). A critique of the mental disorder: perspective of political terrorism. International Journal of Law and Psychiatry, 4, 3-4, 293-309.

Crenshaw, M. (1992). How terrorists think: What psychology can contribute to understanding terrorism. L. Howard (Ed.) Terrorism: Roots, impact, responses. New York: Praeger. 
Crossman, A. (2017). Learn about rational choice theory. Online @: $\quad$ http://www. thought.co.com>science. tech.math $>$ socialscience $>$ sociology $>$ kev.theoreticalconccpts.html. Accessed $10^{\text {th }}$ October, 2017.

Ekanola, A.B. (2006). National integration and the survival of Nigeria in the $21^{\text {st }}$ century. On Africa, 31, 3, 279-293.

Eme, O. I. \& Ibietan, J. (2012). The cost of Boko Haram activities in Nigeria. Arabian Journal of Business and Management Review (OMAN Chapter), 2, 2, 10-32.

Endner, N. \& Sandier, T. (2002). Patterns of transnational terrorism, 1970-1999: Alternative time series estimates. International Studies Quarterly, 46, 145-146.

Fotion, N., Kashnikov, B. \& Lekea J. K. (2017). Terrorism: The new world disorder. London: continuum.

Friedland, N. (1992). Becoming a terrorist: Social and individual antecedents. L. Howard (Ed.). Terrorism: Roots, impacts, responses. New York: Praeger.

Gardner, F. (2014). Have Boko Haram over-reached themselves? Online@ @ttp://www.bbc.com/news/world-africa27334894. Accessed 10 ${ }^{\text {th }}$ February, 2015.

Hodffan, B. (1997). The confluence of international and domestic trends in terrorism. Terrorism and Political Violence, 9, 2, 1-15. Online @ doi::0.1080/0954655970827399. Accessed $10^{\text {th }}$ October, 2017. 
Imhonopi, D. \& Urim, U. M. (2016). The spectre of terrorism and Nigeria's industrial development: A multi-stakeholder imperative. African Journal of Criminology and Justice Studies, 9, 1, 20-40.

Lizardo, O. (2008). Defining and theorizing terrorism: A global actor-centred approach. Journal of World-Systems Research, XIV, 2, 91-118.

McCauley, C. (2002). Psychological issues in understanding terrorism and the response to terrorism. C.E. Stout (Ed.). The psychology of terrorism: Theoretical Understanding and Perspectives. Westport: Praeger.

Moss, S. (2016). The rational choice theory of terrorism. Online @ http://www.sicotest.com/psyarticle.asp?id=37Q.html. Accessed $10^{\text {th }}$ October, 2017.

Nzomiwu, I.P.C. (2012). Trends in religion and society/Christian ethics. A.B.C. Chiegboka (Ed.). Awka: Fab ,

Obiefuna, B. A. C. \& Adams, P. A. (2017). Terrorism and peace building in Nigeria: Lessons from Boko Haram insurgency. NOCE International Journal of Arts and Social Science, 1, 2, 1-29.

Obiefuna, B. A. C. \& Adams, P. A. (2021). The plights of females internally displaced persons in Borno State: The responses of Christian Association of Nigeria (CAN). IGWEBUIKE: African Journal of Arts and Humanities, 7,1, 1-28. 
Ogundiya \& Amzat J. (2008). Nigeria and the threats of terrorism: Myth or reality. Journal of Sustainable Development in Africa, 10,(2)165-189.

Ojewale, O. (2021). Rising insecurity in Northwest Nigeria: Terrorism thinly disguised as banditry. Online @ www.brookings.edu/blog/africa-infocus/2021/02/18/rising-insecurity-in-northwet-nigeriaterrorism-thinly-disgusied-as-banditry/ Accessed $18^{\text {th }}$ August, 2021

Ome, E.M. \& Casmir A. (2015). Re-examining religious insecurity in the African state: The menace and security challenges of Boko Haram in Nigeria. Open Journal of Political Science, 5, 95-101.

Onuoha, F.C. (2012). (Un) Willing to die: Boko Haram and suicide terrorism in Nigeria, Al-jazeera centre for studies. Online @ http://www.studies.aljazeera.net. Accessed 5 ${ }^{\text {th }}$ October, 2013.

Ozdamar, O. (2008). Theorizing terrorist behaviour: Major approaches and their characteristics. Defence Against Terrorism Review, 1, 2, 89-101,

Rawls, J. (1971). A theory of justice. Cambridge: Harvard University Press.

Rogers, P, (2012). Nigeria: The generic context of the Boko Haram violence. Oxford Research Group. Monthly global security briefing. 30 $0^{\text {th }}$ April, 2012. 
Ruby, C.L. (2002). Are terrorists mentally deranged? Analyses of Social Issues and Public Policy, 2, 1, 15-26.

Ruby, C.L. (2002). The definition of terrorism. Analyses of Social Issues and Public Policy, 2,9-14.

Sageman, M. (2004). Understanding terror networks. Philadelphia: University of Pennsylvania press.

SBM Intelligence(2021). SITREP Nigeria State: Terrorist take over. Retrieved online @ : reliefweb.int/report/Nigeria/sitrep-niger-state-terroriststake-over-febraruy-2021. Access 18 August, 2021.

Silke, A. (1998). Cheshire-cat logic: The recurring theme of terrorist abnormality in psychological research. Psychology, Crime and Law, 4, 1, 51-69.

Spiering, C. (2015). President Obama: "No religion is responsible for violence and terrorism". Online @ http://www.breitbart.com/big-government/ 2015/02/18/ president-obama-no-religion-is-responsible-for-violenceand-terrorism. Accessed 10 ${ }^{\text {th }}$ October, 2017.

Stern, J. (1999). The ultimate terrorists. Cambridge: Harvard University Press. 151-167.

Tilly, C. (2004). Terror, terrorism, terrorists. Sociological Theory, $22,5-13$, 
Victoroff, J. (2005). The mind of the terrorist: A review and critique of psychological approaches. Journal of Conflict Resolution, 49, 3-42.

Webster's Integrated Dictionary and Thesaurus (2006). New Lanark: Geddes \& Grosset, p. 509-510.

Webster's Universal Dictionary and Thesaurus (2008). New Lanark: Geddes \& Grosset, p. 271.

Wilson, M.A. (2000). Toward a model of terrorist behaviour in hostage-taking incidents. Journal of Conflict Resolution, 44,304-324.

http://dx.doi./org/10.4314/ujah.v22i1.2 